\title{
ISSN:
}

Print - $2277-0755$

Online - $2315-7453$

(C) FUNAAB 2016

Journal of

Agricultural

Science

and Environment

\section{GIS - SUPPORTED ASSESSMENT OF LAND USE DYNAMICS OF ABEOKUTA METROPOLIS FROM 1960 T0 2005}

\author{
B. O. ADELEKE AND O.O.I. ORIMOOGUNJE
}

Department of Geography, Obafemi Awolowo University, Ile-Ife, Nigeria

*Corresponding author: nicfem2002@yahoo.com, adelekeoluwafemi.ao@gmail.com

\begin{abstract}
The study identified and analyzed land use patterns between 1960 and 2005, and examined the forces underlying land use change and projects the future pattern of land use change in the study area. Both primary and secondary data collected were analyzed using descriptive statistics and geospatial techniques of GIS and Remote Sensing. The results showed that settlement land use which was 1253.12 hectares (3\%) in 1972 increased by six fold to 7684.27 hectares (16\%) in 1984 and by tenfold to 12842.11 hectares (27\%) of the total land area in 2005. Farmlands reduced from 8751.21 hectares (19\%) in 1972 to 7144.32 hectares (15\%) in 1984 to $3824.80(8 \%)$ in 2005. The result equally showed that between 1972 and 1984 the population grew by $75.16 \%$ while settlements increased by $513.21 \%$. Also between 1972 and 2005 the population grew by $206.70 \%$ and settlements increased by 924.81 $\%$. The result of the predictive model developed for this study showed that settlement, bare surface, shrub and water body will increase by $60.30 \%, 57.68 \%, 53.79 \%$ and $8.03 \%$ respectively while nonforested, farmlands, forested wetlands and light forest will decrease by $9.5 \%, 28.55 \%, 12.35 \%$ and $26.76 \%$ respectively. There were continuous changes among the various land use classes identified.
\end{abstract}

Keywords: Environment, Geographic Information System, Human activities, Land use Dynamics, Remote sensed data, Sustainability

\section{INTRODUCTION}

Land use and Land cover changes have emerged as the most significant regional and global anthropogenic disturbance of the environment in the 20th century (EEC, 2006). Almost all the cities and towns in the world are undergoing sprawling growth in the face of rapid population increase, technological advancement and high economic development (Adegboyega 2010). The emerging rapid urbanization / industrialization and large scale agriculture are some of the major changes in human activities that have been identified as the major causes of the dramatic changes in land cover and land use patterns globally (Ademiluyi, et al, 2008). These changes have therefore led to a situation whereby environmental modifications that would have once required centuries now take place within a few decades. It has been established that Africa has the fastest rate of deforestation in the world, competing land uses (agriculture and human settlements mainly) are contributing to the decline of 
GIS - SUPPORTED ASSESSMENT OF LAND USE DYNAMICS OF ABEOKUTA ...

forest and woodland areas. The rising demand for fuel wood and charcoal is also a major cause of deforestation. Over harvesting, agricultural encroachment and unregulated bush burning are believed to be contributing to the decline of many species in the wild. However, agricultural expansion and urbanization are among the major causes of land use / landcover changes (Geist $e t$ al., 2005; Reid et al., 2005). As a result of human interference, the natural form, structural characteristics, species composition, density and distribution pattern of the original vegetation have been remarkably altered.

The global pattern and impacts of increased urbanization and urban development are also apparent in many regions worldwide (Marzluff, 2001 and Alberti et al., 2003). Studies have equally shown that there remain only few landscapes of the earth that is still in their natural state (Fanan et al, 2011; FAO, 2003a). Due to anthropogenic activities, the earth surface is being significantly altered in some manner. Man's presence on earth and his use of land has had profound effects upon the natural environment, thus, resulting into an observable pattern in the land use / landcover over time (Zubair, 2006). And the use to which lands are put could either be temporal or permanent. While agricultural related land use for cash crop plantation or forest reserves are temporal in nature, urban expansion in housing constructions, road construction extensions, and industrialization expansions are permanent land use changes and most times irreversible.

Presently, unplanned changes of land use through urbanization processes in our major cities, and the accompanied almost irreversible land use changes coupled with the replacement of natural surface materials by those used in construction are on the increase. In addition, the releases of waste products of urban metabolism are equally responsible for most of the observed changes in land use which are on the increase today (Lohman, 2006). Environmental variability alters land use practices differently in different parts of the world, highlighting differences in regional and national vulnerability and resilience. In East Africa and other parts of Africa for instance, the main cause of land use change due to deforestation was no longer local encroachment on forested areas for farming or high subsistence use, nor illegal logging but illegal settlements (Ademiluyi, et al, 2008). Also in the face of declining export earnings and debt burdens, many governments tried to boost the exploitation of natural resources and cash crop production. This has equally led to widespread environmental damage, as rural communities are forced to cultivate fragile and marginal areas (UNEP, 2002).

The land use changes due to urban land expansion seemed to be impacting most negatively on the vegetation cover. Several hectares of which had been replaced with human induced land use in the guise of urbanization. This unguided urban expansion has been the fate of many existing and emerging cities both in the developed and developing countries in the world.

Like many other state capitals and major cities in Nigeria, Abeokuta has experienced steady growth since it came into existence in 1830. In 1839 Abeokuta became the seat of Egba United Government courtesy of the British Government (Adenekan 2000). Ever since, Abeokuta has been growing in leaps and bounds and its development monitored and documented in various forms such as, aerial photographs and topographic maps. 
The city has witnessed remarkable expansion, growth and development including increase in residential and commercial buildings, multiple road construction, associated with deforestation and many other terrain altering anthropogenic activities. The city's growth rate dramatically changed with the assumption of capital city status when Ogun State was created in1976. This resulted in increase in land consumption, modification and alteration. Incidentally, there has not been any serious attempt to check the continuous changes taking place, and to evaluate the status of the land cover changes over time. The impacts of land cover changes are serious both in the short and in the long terms. In the short term, food security, human vulnerability, health and safety are at stake: in the longer term the viability of the earth is being threatened (Olaleye et al 2009). With rapid urbanization and a finite land area, the available land per individual shrinks drastically. The result is an urgent need for proper management of land, and this is dependent upon the availability of a detailed, accurate and up-to-date data.

Land use dynamics is essential in order to examine various ecological and developmental consequences of land use change over a space of time. This makes land use mapping and change detection relevant inputs in decision-making for implementing appropriate policy responses (Fasona and Omojola et al., 2005). Consequently an improved understanding of historical land use and landcover patterns will provides a means to evaluate complex causes and responses in order to have a better projection of the future trends of human activities and land use and landcover changes. Through such effort, it will be possible to mitigate the consequences of land alteration with respect to indiscriminate conversion of forest to urban centres without recourse to the likely effect of such actions on the environment.

There is need to understand the primary, modern and future drivers of land use and their interrelationship with land management decisions outcomes under a range of economic, environmental and social scenarios. This will provide a framework for making better projections and hopefully minimize negative impacts, especially those that are related to the use to which a piece of land is to be put. In essence, this type of analysis requires an interdisciplinary approach; basically an integration of physical and social sciences. The aim of this study is to develop a predictive model for land use changes with a view to monitoring anthropogenic activities in Abeokuta metropolis for healthy and sustainable environment. While the specific objectives are to;

1. identify and analyze land use patterns between 1960 and 2005 in the study area;

2. examine the driving forces underlying land use changes in the study area;

3. determine the hot spots of land use / land cover changes in the study area; and

4. forecast the future pattern of land use / land cover changes in the study area.

\section{Study Area}

The study area is Abeokuta township, it occupies an area of 100 square kilometres with an estimated population of about 593,100 (NPC, 2007). The area lies within the rain forest belt of the tropics, between latitude $07^{0} 5^{1}$ and $07^{0} 20^{\prime} \mathrm{N}$ and longitude $03^{0} 17^{1}$ and $03^{\circ} 27^{\prime}$ E. (Onakomaiya, 2000). The altitude ranges from 120 to $180 \mathrm{~m}$ above sea level. The dominant feature of the area is the Ogun River which flows from north to 
south draining the city through a number of rivers such as Ona-Ibu River in the southeast, the Osun in the east, Yewa in the west and Ewekoro and Adiyan Rivers in the south-west (Oyegoke et al 2012). Abeokuta enjoys a tropical climate with distinct wet and dry seasons, with rainfall ranges from

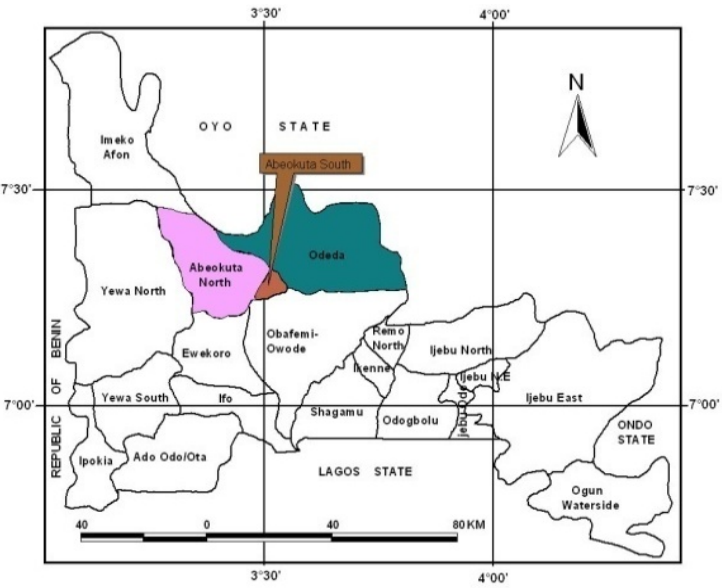

Figure 1: Map of Ogun State showing the Study Area
$1016 \mathrm{~mm}$ to $1270 \mathrm{~mm}$ (NEAFR, 2002, NiMet, 2016). It is underlain by both the crystalline basement rocks and the Cretaceous Sedimentary formation (Aketoyon, et al, 2010).

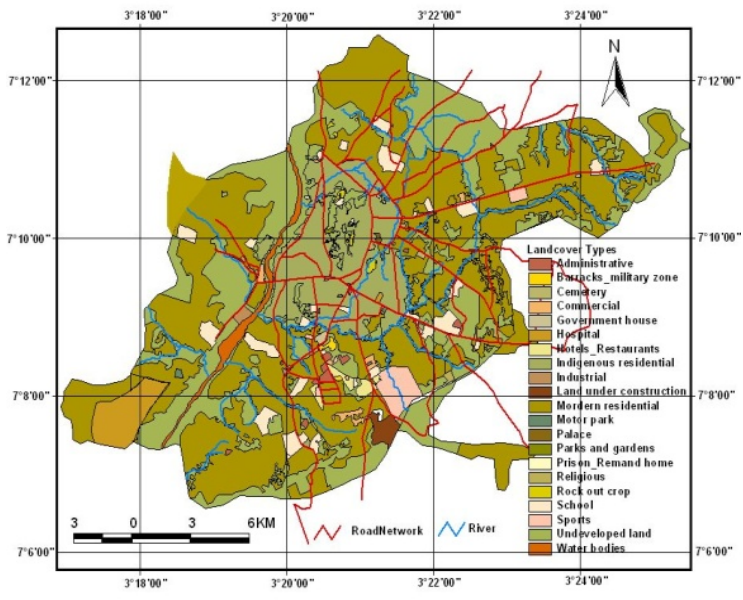

Figure 2: Map of the Abeokuta Metropolis Showing the Landcover Types

Source: Author map work, 2012

Abeokuta lies within the tropical rainforest with the tall ever green trees; like the Swietenia Genus, Ttriplochiton scleroxylon, Diospyros, Lianas, Milicia excelsa, Entandrophragma cylindricum and Juglans Genus, with an undergrowth of lians and other climbing plants which may become so entangled to make penetration impossible. The forest protects the soil from erosion; heavy leaf-fall provides the soil with humus. The economic value of the trees is enhanced by their long, straight and branched stems. Although, with the damp condition that exists inside the forest, damage by insects, fungi or other parasitic growths are not uncommon. There is a great variety of species of which the merchantable include; the most evergreen types such as Entandrophragma spp, Khaya invorensis, Piptaderuastrum africanum (Solanke,
2014).

\section{MATERIALS AND METHODS Data types and collection}

The data for this study were derived from both primary and secondary sources. The primary data include geometric coordinates established with the aid of Global Positioning System (GPS), while questionnaires were administered to obtain data on the socio-economic implication of land use dynamics in the metropolis. A total of six hundred and fifty questionnaires were used as a percentage of the projected population of 616,473 people for the study area in 2011. The secondary data however was obtained from the 1962 topographic map of Abeokuta on scale of 1:50,000 and three 
Multidate Satellite Imageries; Landsat MSS 1972, Landsat TM 1984 and Landsat ETM 2005. The topographic map of Abeokuta (1962) was taken as the base year map and to ensure randomness in the selection of the imageries. The study epoch was first divided into three periods of sixteen years with an imagery selected for each interval. The division of the scope of study into the sixteen year periods provided the opportunity of observing the changes that are taken place among the various land use classes within the periods. However, for the administration of questionnaires, stratified sampling and simple random sampling procedures were adopted. By dividing the study area into five strata in line with the traditional divisions of Egba into quarters as follows; Egba, Owu, Egba Oke-Ona, Gbagura and Ibara, of Abeokuta (Adenekan, 2000). Streets within the strata were selected randomly for the administration of the questionnaires.

\section{Data processing and analysis}

The obtained Topographic map of 1962 was scanned and imported into the GIS environment, various land use patterns, other spatial features were digitized (using onscreen digitizing technique), and Abeokuta metropolitan landcover map was generated. Submaps of the study area were created from the satellite images of Abeokuta region using visual image interpretation technique. On each of the submaps created from multi-spectral images (Landsat imageries of; 1972, 1984 and 2005), colour separation and colour composite operations were performed. These images were enhanced and filtered using linear contrast enhancement and high frequency filter techniques respectively. The images were georeferenced and supervised image classification operation was carried out on each of them. The operations were combined with ground truthing of the study area. From the classified images land use patterns were identified and digitized. The operation created eight classes of land uses which were arranged in layers, thus, light forest, forested wetlands, non-forested wetlands, shrubs, farmlands, settlements, bare ground / rock out crops). Overlay operations were subsequently carried out to obtain and detect changes among the imageries used; and linear regression of the variables obtained from the area coverage for each year.

The transition matrix tables provided the bases for comparison of percentage gained and loss among differences land uses classes and forecasting. Simple forecasting equations of the form $L_{n}=L_{o}(1+r / 100)^{n}$ was adopted for the projections of the likely land use change (where; $\mathrm{L}_{\mathrm{n}}=$ Land use value forecasted, $\mathrm{L}_{\mathrm{o}}=$ Land use value taken as the base, $\mathrm{r}=$ Annual growth rate of specific Land use, $\mathrm{n}=$ Number of years between $\mathrm{L}_{\mathrm{o}}$ and $\left.L_{n}\right)$. ArcGIS software 9.6 versions were utilized to produce land use / landcover maps of the projected land areas. Abeokuta metropolis was demarcated on the 1962 Topographic map, and on the satellite imageries to show the extent of its spatial growth on the periphery over the study periods. The 1972, 1984 and 2005 population figures were estimated from the 1991 and 2006 census figures of Abeokuta (NPC 2007), using the recommended $2.86 \%$ growth rate. The status of land use / landcover classes and the projected population for the year 2020 was obtained in order to observe the future status of the land use (MDG, 2007). The socioeconomic implication of change was evaluated, by observing the effect of changes in the land use / landcover values and dynamics of population between 1972 and 2005, and analysis of the administered questionnaires. 


\section{Table 1: Areal Coverage of the Land Use/Land Cover Classes between 1972 and} 2005

\begin{tabular}{lllllll}
\hline LULC Types & \multicolumn{2}{l}{1972 LULC Area } & \multicolumn{2}{l}{ 1984 LULC Area } & \multicolumn{2}{l}{ 2005 LULC Area } \\
& Ha & $\%$ & Ha & $\%$ & Ha & $\%$ \\
\hline Settlements & 1253.12 & 2.663 & 7684.27 & 16.332 & 12842.11 & 27.295 \\
Non-Forested Wet- & 10906.08 & 23.180 & 9165.54 & 19.480 & 7888.13 & 16.765 \\
lands & & & & & & \\
Farmlands & 8751.21 & 18.600 & 7144.32 & 15.185 & 3824.80 & 8.129 \\
Forested Wetlands & 6480.61 & 13.773 & 5101.5 & 10.843 & 4164.42 & 8.851 \\
Shrub & 2932.47 & 6.223 & 3695.03 & 7.853 & 5953.66 & 12.654 \\
Bare Surface & 6853.8 & 14.567 & 3342.4 & 7.104 & 2239.66 & 4.760 \\
Light Forest & 4681.5 & 9.950 & 3634.24 & 7.724 & 2065.87 & 4.391 \\
Water Body & 5191.07 & 11.033 & 7282.56 & 15.478 & 8071.21 & 17.155 \\
TOTAL & 47049.86 & 100.00 & 47049.86 & 100.00 & 47049.86 & 100.00 \\
\hline
\end{tabular}

\section{Source: Image Classification Analysis}

Table 1 illustrates that the prevailing situation in 1972 (period 1960-1975) was that of semi rural settings, with settlement lands taken up the smallest classes of 1253.12 hectares $(2.66 \%)$ and farmlands 8751.21 hectares $(18.66 \%)$ (Figure 3). The highest class was at the instance of non-forested wetlands with total coverage of 10906.08 hectares $(23.18 \%)$ and forested wetlands covered $6480.61(13.77 \%)$. All these statistics depicted a rural setting with lower population of 172,090 (Table 4) who were predominantly farmers. However as the year progressed, 1984 and 2005, as the population increased to 301,440 and 527,803 respectively, there was a corresponding decrease in the farmlands and other forest related land uses, with consistent increase in the settlement lands. This confirmed the opinion expressed by Harcourt (1992) in Kenya that increase in the number of the people caused deforestation.

However in 1984, (1976-1991) there was a sharp deviation from what was obtained in
1972, during when Abeokuta assumed the status of state capital. The period witnessed a sharp increase in the settlements lands and the population from 1253.12 hectares with 172,090 people in $1972(2.663 \%)$ to 7684.27 hectares and 301,330 people of 1984 $(16.33 \%)$. This confirmed the view of, ITC, in 2005 which estimated that more than five billion people will live in urban areas by 2005, eighty per cent of which are expected to live in cities in developing countries. Urbanization at such a scale will aggravate land use conversion from forest cover to settlement and other, destructive human activities. This claim was equally affirmed by the United Nations Food and Agricultural Organization (FAO) that indigenous (also known as 'old growth) forests in Africa are being cut down at a rate of more than 4 million hectares per year- twice the world's deforestation average. The losses stemming from such a practice account for more than 10 percent of the continent's total forest cover between 1980 and 1995 alone (Ademiluyi, 2008). From the foregoing the environments are 
under pressure from urban growth as numbers of households have grown faster than the population, reflecting a trend to smaller families and invariably a decline in the average number of people per household (Figure 4).There was equally a decrease in non-forested wetlands, forested wetlands and farmlands, 9165.55 (19.48\%), 5101.5 $(10.84 \%), 7144.32(15.18 \%)$ respectively. Bare surface lands of $3342.4(7.10 \%)$ too was not left out in the emerging trend of reduction in their areal coverage in the year 1984. Mainly to provides lands for more housing unit and other developmental purposes in the metropolis. This was confirmed by the findings of Martine, (2011) while writing on the emerging trends of increasing encroachment of settlements related land use on agricultural and natural land areas, he posited the detrimental consequences to include among other things population related generation of pollution, through massive deforestation. And bare surface and light forest occupied the least values of 3342.4 hectares $(7.104 \%)$ and 3634.24 hectares $(7.724 \%)$ respectively in the classes during the period.

The increase in lands taken up by settlements continues into 2005 (the period 1991 -2005), with 12,842.11 hectares (27.29\%), from 7684.27 hectares occupied in the year 1984. This implied more households were being erected and lands hitherto occupied by other land cover were being encroached into. Mostly affected were the farmlands which had their land coverage reduced from 7144.32 hectares of 1984 to 3824.80 hectares in 2005 (Figure 5). Other land uses were not exempted in the encroachment spree by the settlements development due to rapid urbanization that was taking place. The non-forested wetlands coverage reduced from $19.480 \%$ of the total land areas to $16.765 \%$ between 1984 and 2005, this could be as a result of increase in vegetable gardening / cultivation for the town dwellers fresh vegetable needs. Forested wetlands, bare surface and light forest occupied 8.851, 4.760 , and 4.391 percentages respectively, This, according to Fritts (2005), highlighted the costs imposed on the society and environment as a whole by urbanization which included loss of wetlands that provided flood control and waste water renovation, ecosystem destruction and loss of agricultural lands. Meanwhile, there was increase in the area coverage of shrubs land from 3695.03 hectares in the year 1984 to 5953.66 hectares in 2005 , the increase in shrubs land could have been due to increase need for town beautification through planting of ornamental plants and orchard growing. Water body also increased from 7282.56 hectares to 8071.21 hectares as a result of loss of wetlands that provided flood control and waste water renovation, reduction in water retention capacity of the soil, with resultant increase in runoff and occasional flooding Fritts (2005). Little will one wonder about the incidence of incessant flooding during torrential downpour in the recent past in many parts of Abeokuta metropolis.

\section{Land use / Landcover Change between 1972 and 2005}

The result of land use change between 1972 and 2005 presented in Table 2, show the trend and rate of changes and the nature of changes. The absolute and percentage rates of land use changes for the periods: 19721984, 1984-2005 and 1972-2005. 
GIS - SUPPORTED ASSESSMENT OF LAND USE DYNAMICS OF ABEOKUTA ...

Table 2: Comparison of Land Use/Land Cover Change between 1972 and 2005

\begin{tabular}{lllllll}
\hline LULC Types & \multicolumn{2}{l}{$\begin{array}{l}\text { Change between 1972 } \\
\text { and 1984 }\end{array}$} & $\begin{array}{l}\text { Change between 1984 and } \\
\text { 2005 }\end{array}$ & \multicolumn{2}{l}{$\begin{array}{l}\text { Change between 1972 } \\
\text { and 2005 }\end{array}$} \\
\cline { 2 - 7 } & Ha & $\%$ & Ha & $\%$ & Ha & $\%$ \\
\hline Settlements & +6431.15 & +513.211 & +5157.84 & +67.122 & +11588.99 & +924.811 \\
Non-Forested Wetlands & -1740.54 & -15.959 & -1277.41 & -13.937 & -3017.95 & -27.672 \\
Farmlands & -1606.89 & -18.362 & -3319.52 & +46.464 & -4926.41 & -56.294 \\
Forested Wetlands & -1379.11 & -21.281 & -937.08 & -18.369 & -2316.19 & -35.740 \\
Shrub & +762.56 & +26.004 & +2258.63 & +61.126 & +3021.19 & +103.025 \\
Bare Surface & -3511.4 & -51.233 & -1102.74 & -32.992 & -4614.14 & -67.322 \\
Light Forest & -1047.26 & -22.370 & -1568.37 & -43.155 & -2615.63 & -55.872 \\
Water Body & +2091.49 & +40.290 & +788.65 & +10.829 & +2880.14 & +55.483 \\
\hline
\end{tabular}

\section{Source: Image Classification Analysis}

From Table 2 there was a negative change, that is, loss of 1606.89 hectares (a reduction of $18.362 \%$ ) in farmlands between 1972 and 1984. This may be due to the changes in the economic base of the city from farming to other means of livelihood including white collar jobs. The urbanization of Abeokuta, following the creation of Ogun State in 1976, accounts for this kind of socioeconomic transformation. This was accompanied with corresponding increase in the settlement lands by $513.21 \%$, and both bare surface and light forest decreased by $51.23 \%$ and $22.37 \%$ respectively. The foregoing thus confirmed the rapid urbanization of the cities in the developing countries posited by Oyinloye, (2003) and Menon, (2004)

The period between 1984 and 2005 witnessed a drop in the rate at which the physical expansion of the city was growing as against the period between 1972 and 1984 . Here, the settlement lands only increased by $67 \%$, as against the increase of $513.211 \%$ from years 1972 to 1984 and $924.811 \%$ between years 1972 and 2005. However, there exists a continuous decrease of $46 \%$ in farmland, 33\% in bare surface and $43 \%$ in light forest. Hence the physical expansion of the city was still ongoing, though at reduced rate. Furthermore, water body seems to maintain its increased potential throughout the periods with $10.829 \%$ gaining additional 788.65 hectares in areal extent. Also, this period witnessed a continuous growth in settlements lands with $11,588.99$ hectares that is about $925.811 \%$ increase from the previous period. Meanwhile, non-forested wetlands, farmlands, forested wetlands, bare surfaces and light forest experienced negative growth of $-3017.95,-4926.41,-2316.19,-4614.14,-$ 2615.63 hectares respectively.

Nonetheless, there are positive increase of 3021.19 and 2880.14 hectares in shrubs and water body lands respectively.

The transition matrix tables; 3,4 and 5 provided bases for the comparison of percentage lands gained or loss among various land use/ landcover classes in the study area between years 1972 and 1984, 1984 and 2005 and 1972 and 2005 respectively in hectares. Loss to a class indicated an encroachment on that particular class by other class(es). In the 
same way, gain to a class was an emergence of that particular class on other class(es), and no change areas implied a spatially consistent situation or unchanged part of a particular land use / landcover. The diagonal figures on the tables indicated the condition of stability among the various classes; it emphasized a state where the various land use classes classified are experiencing little or no change in their area coverage during the period under investigation. From the three transition matrix tables it can be concluded that there was instability among the various land use classes throughout the time of study. Such situation brought to the fore ground the influence of man and by implication population increase, which constituted the main force of land use dynamics in the area and elsewhere (Tables 3, 4 and 5, Hardoy et al, 2002).

Table 3: Transition Matrix Table of Land use Classes between 1972 and 1984

\begin{tabular}{|c|c|c|c|c|c|c|c|c|c|}
\hline \multicolumn{10}{|c|}{ Land use/Landcover (LULC) } \\
\hline 1972 & $\begin{array}{l}\text { Settle- } \\
\text { ments }\end{array}$ & $\begin{array}{l}\text { Non- } \\
\text { Forested } \\
\text { Wetlands }\end{array}$ & $\begin{array}{l}\text { Farm- } \\
\text { lands }\end{array}$ & $\begin{array}{l}\text { Forested } \\
\text { Wetlands }\end{array}$ & Shrub & $\begin{array}{l}\text { Bare } \\
\text { Surface }\end{array}$ & $\begin{array}{l}\text { Light } \\
\text { Forest }\end{array}$ & $\begin{array}{l}\text { Water } \\
\text { Body }\end{array}$ & Total 1972 \\
\hline \multirow{2}{*}{$\begin{array}{l}\text { Settle- } \\
\text { ments }\end{array}$} & 1253 & 0.4 & 0.00 & 0.00 & 0.00 & 0.3 & 0.00 & 0.5 & 1253.12 \\
\hline & 99.990 & 0.032 & 0.00 & 0.00 & 0.00 & 0.024 & 0.00 & 0.039 & 100.00 \\
\hline \multirow{2}{*}{$\begin{array}{l}\text { Non- } \\
\text { Forested } \\
\text { Wetlands }\end{array}$} & 202.04 & 7187.48 & 1775 & 50 & 450 & 70 & 0.00 & 1171.56 & 10906.08 \\
\hline & 1.852 & 65.903 & 16.275 & 0.458 & 4.126 & 0.641 & 0.00 & 10.742 & 100.00 \\
\hline \multirow[t]{2}{*}{ Farmlands } & 4111.86 & 180.02 & 2572.58 & 20.05 & 146.65 & 525.05 & 75 & 1120 & 8751.21 \\
\hline & 46.986 & 2.057 & 29.396 & 0.229 & 1.675 & 5.999 & 0.857 & 12.798 & 100.00 \\
\hline \multirow{2}{*}{$\begin{array}{l}\text { Forested } \\
\text { Wetlands }\end{array}$} & 0.00 & 141.74 & 120.09 & 4750.68 & 1368 & 0.00 & 0.00 & 100.10 & 6480.61 \\
\hline & 0.00 & 2.187 & 1.853 & 73.306 & 21.109 & 0.00 & 0.00 & 1.544 & 100.00 \\
\hline \multirow[t]{2}{*}{ Shrub } & 60.07 & 750 & 100.15 & 50.25 & 972 & 350 & 250 & 400 & 2932.47 \\
\hline & 2.048 & 25.575 & 3.415 & 1.713 & 33.146 & 11.935 & 8.525 & 13.640 & 100.00 \\
\hline \multirow{2}{*}{$\begin{array}{l}\text { Bare Sur- } \\
\text { face }\end{array}$} & 1800.3 & 485.9 & 1188.5 & 0.00 & 08.35 & 1897.03 & 636.24 & 836.4 & 6853.8 \\
\hline & 26.267 & 7.089 & 17.340 & 0.00 & 0.121 & 27.678 & 9.283 & 12.203 & 100.00 \\
\hline \multirow{2}{*}{$\begin{array}{l}\text { Light } \\
\text { Forest }\end{array}$} & 220 & 20 & 1038 & 80.5 & 550 & 250 & 2423 & 100 & 4681.5 \\
\hline & 4.699 & 0.427 & 22.172 & 1.719 & 11.748 & 5.340 & 51.756 & 2.136 & 100.00 \\
\hline \multirow{2}{*}{$\begin{array}{l}\text { Water } \\
\text { Body }\end{array}$} & 37 & 400 & 350 & 150.02 & 200.03 & 250.02 & 250 & 3554 & 5191.07 \\
\hline & 0.712 & 7.705 & 6.742 & 2.889 & 3.853 & 4.816 & 4.815 & 68.463 & 100.00 \\
\hline Total 1984 & 7684.27 & 9165.54 & 7144.32 & 5101.5 & 3695.03 & 3342.4 & 3634.24 & 7282.56 & 47049.86 \\
\hline
\end{tabular}

Source: Image Classification Analysis 
Table 4: Transition Matrix Table of Land use Classes between 1984 and 2005

\begin{tabular}{|c|c|c|c|c|c|c|c|c|c|}
\hline \multicolumn{10}{|c|}{ Land use/Landcover (LULC) } \\
\hline \multicolumn{3}{|l|}{ LULC } & \multicolumn{7}{|l|}{2005} \\
\hline 1984 & $\begin{array}{l}\text { Settle- } \\
\text { ments }\end{array}$ & $\begin{array}{l}\text { Non- } \\
\text { Forested } \\
\text { Wetlands }\end{array}$ & Farmlands & $\begin{array}{l}\text { Forested } \\
\text { Wetlands }\end{array}$ & Shrub & $\begin{array}{l}\text { Bare } \\
\text { Surface }\end{array}$ & $\begin{array}{l}\text { Light } \\
\text { Forest }\end{array}$ & $\begin{array}{l}\text { Water } \\
\text { Body }\end{array}$ & Total 1984 \\
\hline \multirow[t]{2}{*}{ Settlements } & 7596.1 & 2.07 & 0.0 & 2.0 & 0.0 & 44.10 & 0.0 & 40 & 7684.27 \\
\hline & 98.852 & 0.026 & 0.00 & 0.026 & 0.00 & 0.573 & 0.00 & 0.520 & 100.00 \\
\hline \multirow{2}{*}{$\begin{array}{l}\text { Non-Forested } \\
\text { Wetlands }\end{array}$} & 150 & 6712 & 182 & 150.38 & 1020 & 94.76 & 10 & 846.4 & 9165.54 \\
\hline & 1.636 & 73.230 & 1.985 & 1.640 & 11.128 & 1.033 & 0.109 & 9.234 & 100.00 \\
\hline \multirow[t]{2}{*}{ Farmlands } & 3128 & 80 & 1927 & 856.54 & 831.41 & 212.15 & 20 & 89.22 & 7144.32 \\
\hline & 43.783 & 1.119 & 26.972 & 11.989 & 11.637 & 2.969 & 0.276 & 1.248 & 100.00 \\
\hline \multirow{2}{*}{$\begin{array}{l}\text { Forested Wet- } \\
\text { lands }\end{array}$} & 131.8 & 250.5 & 550 & 2530 & 1025.15 & 156.05 & 40 & 420 & 5101.5 \\
\hline & 2.583 & 4.910 & 10.781 & 49.593 & 20.095 & 3.058 & 0.784 & 8.232 & 100.00 \\
\hline \multirow[t]{2}{*}{ Shrub } & 385.62 & 279.22 & 160 & 167.19 & 1763 & 240 & 160 & 540 & 3695.03 \\
\hline & 10.436 & 7.556 & 4.330 & 4.524 & 47.712 & 6.495 & 4.330 & 14.614 & 100.00 \\
\hline \multirow[t]{2}{*}{ Bare Surface } & 846.59 & 10 & 170 & 35 & 510.2 & 1251.19 & 89.42 & 430 & 3342.4 \\
\hline & 25.328 & 0.299 & 5.086 & 1.047 & 15.264 & 37.433 & 2.675 & 12.865 & 100.00 \\
\hline \multirow[t]{2}{*}{ Light Forest } & 250.10 & 30.04 & 642.2 & 243.31 & 550.5 & 150.11 & 1567.98 & 200 & 3634.24 \\
\hline & 6.881 & 0.826 & 17.670 & 6.694 & 15.147 & 4.130 & 43.144 & 5.503 & 100.00 \\
\hline \multirow[t]{2}{*}{ Water Body } & 353.9 & 524.3 & 193.6 & 182 & 253.4 & 91.30 & 178.47 & 5505.59 & 7282.56 \\
\hline & 4.859 & 7.199 & 2.658 & 2.499 & 3.479 & 1.253 & 2.450 & 75.599 & 100.00 \\
\hline Total 2005 & 12842.11 & 7888.13 & 3824.80 & 4164.42 & 5953.66 & 2239.66 & 2065.87 & 8071.21 & 47049.86 \\
\hline
\end{tabular}

\section{Source: Image Classification Analysis}

Table 5: Transition Matrix Table of Land use Classes between 1972 and 2005

\begin{tabular}{|c|c|c|c|c|c|c|c|c|c|}
\hline \multicolumn{10}{|c|}{ Land use/Landcover (LULC) } \\
\hline \multirow{2}{*}{$\begin{array}{l}\text { LULC } \\
1972\end{array}$} & \multirow[b]{2}{*}{ Settlements } & \multicolumn{2}{|c|}{2005} & \multirow[b]{2}{*}{$\begin{array}{l}\text { Forested } \\
\text { Wetlands }\end{array}$} & \multirow[b]{2}{*}{ Shrub } & \multirow[b]{2}{*}{$\begin{array}{l}\text { Bare } \\
\text { Surface }\end{array}$} & \multirow[b]{2}{*}{$\begin{array}{l}\text { Light } \\
\text { Forest }\end{array}$} & \multirow[b]{2}{*}{$\begin{array}{l}\text { Water } \\
\text { Body }\end{array}$} & \multirow[b]{2}{*}{ Total 1972} \\
\hline & & $\begin{array}{l}\text { Non- } \\
\text { Forested } \\
\text { Wetlands }\end{array}$ & Farmlands & & & & & & \\
\hline \multirow[t]{2}{*}{ Settlements } & 1253 & 0.04 & 0.00 & 0.00 & 0.00 & 0.03 & 0.00 & 0.05 & 1253.12 \\
\hline & 99.990 & 0.003 & 0.00 & 0.00 & 0.00 & 0.002 & 0.00 & 0.003 & 100.00 \\
\hline \multirow{2}{*}{$\begin{array}{l}\text { Non-Forested } \\
\text { Wetlands }\end{array}$} & 202.04 & 5910.07 & 775 & 50 & 1450 & 70 & 277.41 & 2171.56 & 10906.08 \\
\hline & 1.852 & 54.190 & 7.106 & 0.458 & 13.295 & 0.641 & 2.543 & 19.911 & 100.00 \\
\hline \multirow[t]{2}{*}{ Farmlands } & 5111.86 & 180.02 & 1572.58 & 20.05 & 146.65 & 422.31 & 177.74 & 1120 & 8751.21 \\
\hline & 58.413 & 2.057 & 17.969 & 0.229 & 1.675 & 4.825 & 2.031 & 12.798 & 100.00 \\
\hline \multirow[t]{2}{*}{ Forested Wetlands } & 0.00 & 141.74 & 120.09 & 3813.6 & 1368 & 78.16 & 0.00 & 957.94 & 6480.61 \\
\hline & 0.00 & 2.187 & 1.853 & 58.846 & 21.109 & 1.206 & 0.00 & 14.781 & 100.00 \\
\hline \multirow[t]{2}{*}{ Shrub } & 217.91 & 750 & 100.15 & 50.25 & 972 & 350 & 250 & 242.16 & 2932.47 \\
\hline & 7.430 & 25.575 & 3.415 & 1.713 & 33.146 & 11.935 & 8.525 & 8.257 & 100.00 \\
\hline \multirow[t]{2}{*}{ Bare Surface } & 3800.3 & 485.9 & 188.5 & 10.82 & 266.98 & 897.03 & 367.87 & 836.4 & 6853.8 \\
\hline & 55.448 & 7.089 & 2.750 & 0.157 & 3.895 & 13.088 & 5.367 & 12.203 & 100.00 \\
\hline \multirow[t]{2}{*}{ Light Forest } & 1220 & 20 & 718.48 & 69.68 & 1550 & 171.84 & 742.85 & 188.65 & 4681.5 \\
\hline & 26.060 & 0.427 & 15.347 & 1.488 & 33.109 & 3.670 & 15.867 & 4.029 & 100.00 \\
\hline \multirow[t]{2}{*}{ Water Body } & 1037 & 400 & 350 & 150.02 & 200.03 & 250.02 & 250 & 2554 & 5191.07 \\
\hline & 19.976 & 7.705 & 6.742 & 2.889 & 3.853 & 4.816 & 4.815 & 49.199 & 100.00 \\
\hline Total 2005 & 12842.11 & 7888.13 & 3824.80 & 4164.42 & 5953.66 & 2239.66 & 2065.87 & 8071.21 & 47049.86 \\
\hline
\end{tabular}

\section{Source: Image Classification Analysis}

J. Agric. Sci. \& Env. 2016, 16(2): 88 -106 


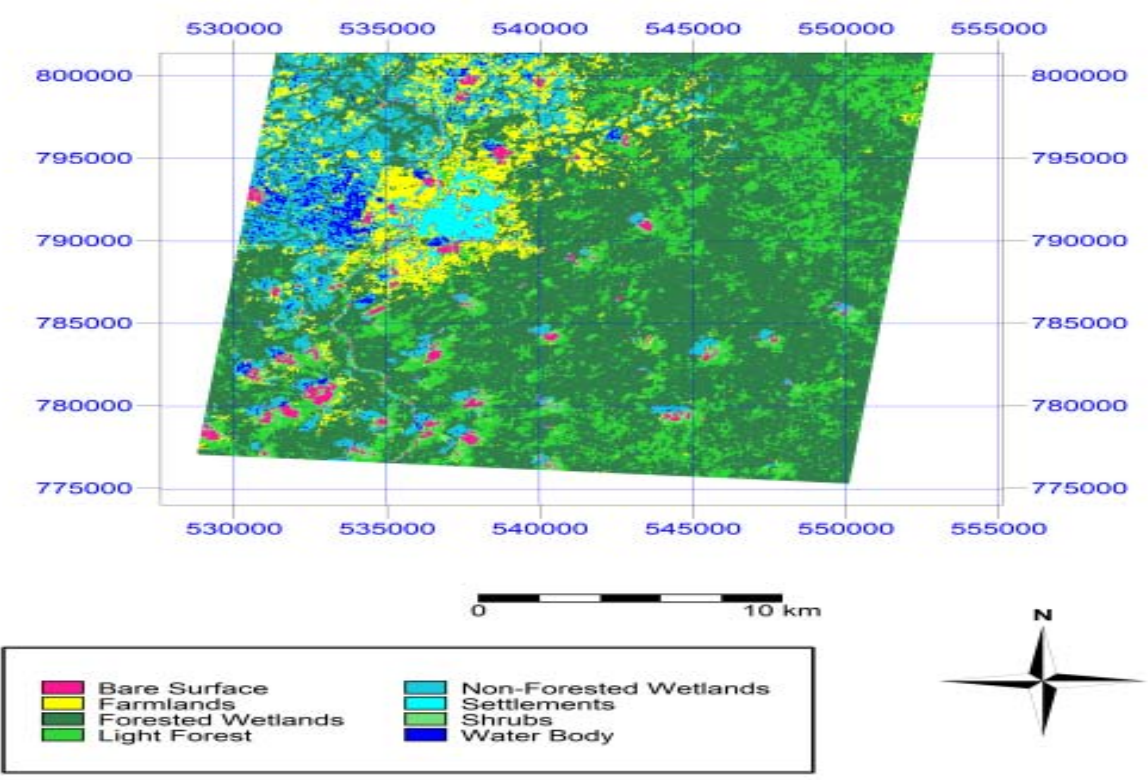

Figure 3: Land Use / Land Cover Map of Abeokuta in 1972: Source Landsat MSS 1972

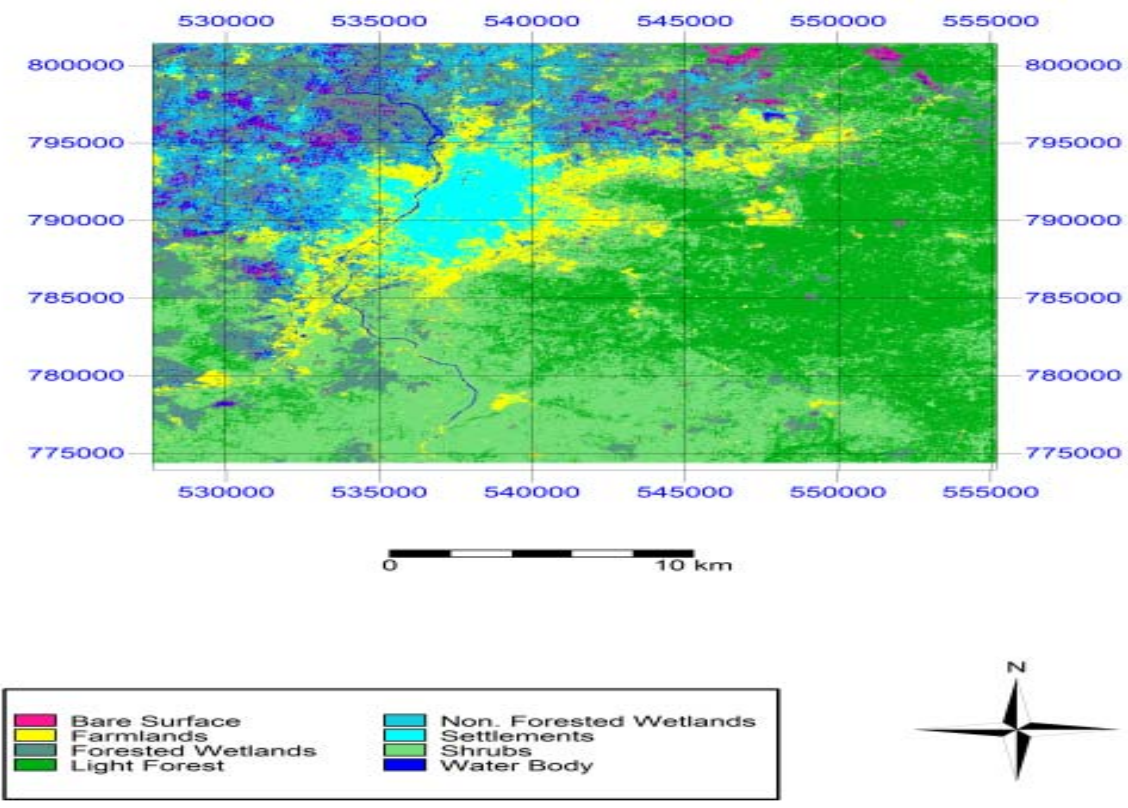

Figure 4: Land Use / Land Cover Map of Abeokuta in 1984: Source Landsat TM 1984 


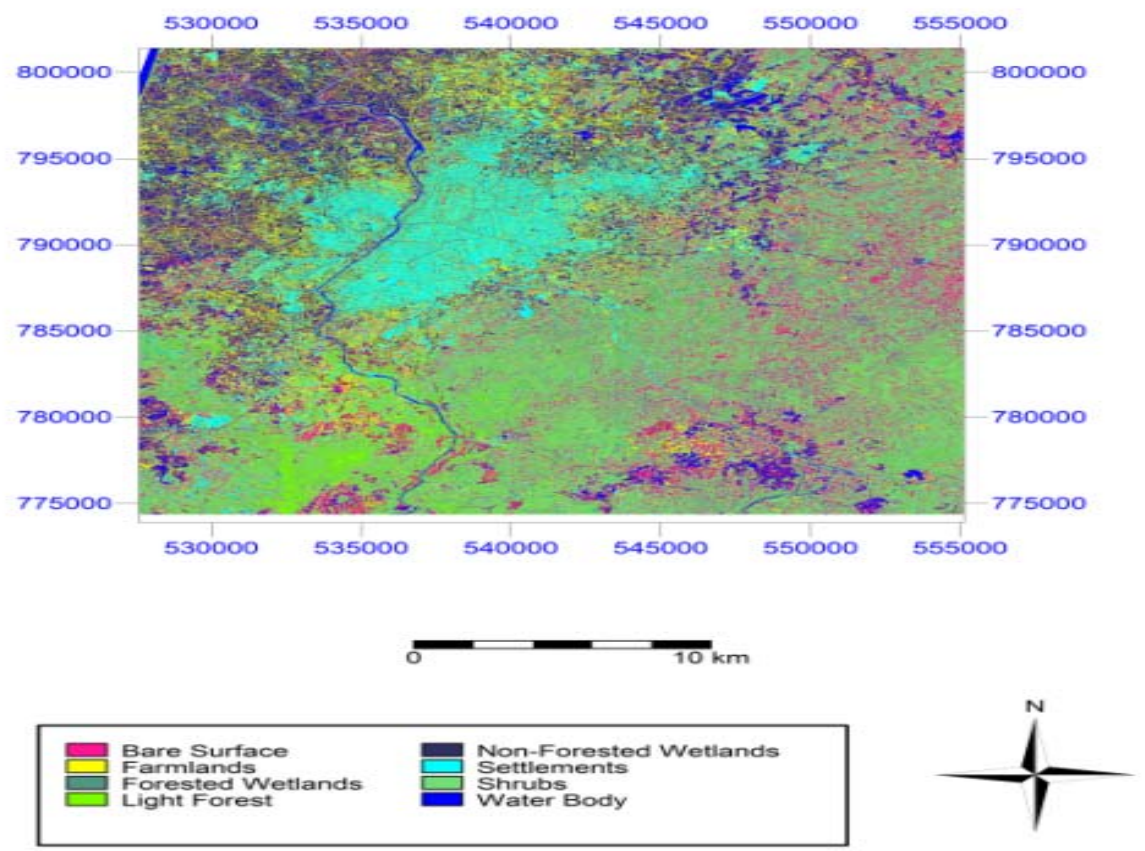

Figure 5: Land Use / Land Cover Map of Abeokuta in 2005; Source Landsat ETM 2005

Table 6: Major Land use Changes in the last 30 Years in the Metropolis

\begin{tabular}{lll}
\hline Land use Change & Frequency & Percentage \% \\
\hline Conversion of Farmlands to Settlement lands & 300 & 46 \\
Indiscriminate Forest removal & 75 & 12 \\
Rock Outcrops Quarrying/Mining & 85 & 13 \\
Deliberate relocation of Farming to the Outskirt & 190 & 29 \\
Total & 650 & 100 \\
\hline
\end{tabular}

\section{Source: Authors Field Survey}

Table 6 confirmed the changes in land use and growth of settlement lands at the expense of other land use types between the years 1972 and 2005. The response of the respondents to the question, what they view was the major shift / changes in land use in the last thirty years; the outcome of the survey shown that $300(47 \%)$ of the respondents affirmed that, the major changes in land use in the metropolis in the last thirty years was heavy conversion of farmlands to settlement land developments. Related to this $190(29 \%)$ of the respondents also agreed that it was deliberate relocation of farming and other primary activities to the outskirt of the metropolis. This is caused by the exigencies of other land uses categories in the metropolis most especially settlement lands. Also $85(13 \%)$ agreed that it was rock quarrying, mining and waste lands reclama- 
tion and developments that constitute the major land use shift, while $75(11 \%)$ agreed it was indiscriminate forest removal. By and large the result of the questionnaires survey confirmed the fact that land use is changing, as expressed by the findings of the imageries classification and analysis carried out.

From the forgoing a number of forces have been identified as the cause of dynamism observed among the land use classes of the study area. These forces in action included but not limited to; the urbanization processes taken place consequent upon rapid population growth and increase demand for housing needs. These activities have led to the massive depletion of forested related land uses; farming lands too were not spared as all the farm lands close to the city was practically encroached by the settlements land use. The expansion was mainly taken place at the fringes in the forms of ribbon urban sprawl, leap frog sprawl and low densely development (Figures; 3, 4 and 5, Adegboyega, 2010). These periphery locations around the fringes constitute the hot spots of land uses in the study areas, most especially settlements expansion (Figures; 3, 4 and 5$)$

Table 7: Population / settlements growth of Abeokuta in 1972, 1984 and 2005

\begin{tabular}{lllll}
\hline Year & Population/1000 & Population change (\%) & Settlements/ha & Settlements change (\%) \\
\hline 1972 & 172,090 & - & 1253.12 & - \\
1984 & 301440 & 75.16 & 7684.27 & 513.21 \\
2005 & 527,802 & 75.09 & 12842.11 & 67.12 \\
\hline
\end{tabular}

Table 7 presented the growth of population in the metropolis during the period with the rate of settlements expansion. In the year 1972 the total population was 172,090 people and the total land area covered by settlements during the same period was 1253.12 hectares. However, in the year 1984 there was a sharp addition of 129,350 people to the population, $(75.16 \%)$. This was followed by a corresponding increase in the settlement lands expansion from 1253.12 hectares of the previous year to 7684.27 hectares $(513.21 \%)$. These trends continued into the year 2005 where the city population increased from 301,440 people of 1984 to 527,802 people in the year $2005(75.09 \%$ change). At the same time $67.12 \%$ improvement was observed in settlement area coverage (12,842.11 hectares). As observed urbanization due to settlements proliferations in Abeokuta, most importantly when it assumed the capital city's status; together with the accompanied population growth due to the; influx of people and other indirect population growth mechanisms like increase birth rate and decrease in death rate as a result of improved health facilities and awareness among the populace. All these factors constitute the major forces engendering the observed land use dynamics in Abeokuta during the period under study. This corroborates the views of Hardoy et al (2002) that recently the cities and towns in developing countries are observed to experience unprecedented growth in size and number. Marshall (2011) argued that increased in number of people caused deforestation in Kenya. Also, as population of cities in developing countries increased dramatically, so have levels of per capital resources consumption, water and air pollution, and soil 
GIS - SUPPORTED ASSESSMENT OF LAND USE DYNAMICS OF ABEOKUTA ...

degradation and contamination (Martine, (2011)).

Table 8: Population and land use patterns of Abeokuta in 1972, 1984 and 2005

\begin{tabular}{llllllllll}
\hline & Population & Settlements & $\begin{array}{l}\text { Non- } \\
\text { Forested } \\
\text { Wetlands }\end{array}$ & Farmlands & $\begin{array}{l}\text { Forested } \\
\text { Wetlands }\end{array}$ & Shrub & $\begin{array}{l}\text { Bare Sur- } \\
\text { face }\end{array}$ & $\begin{array}{l}\text { Light } \\
\text { Forest }\end{array}$ & $\begin{array}{l}\text { Water } \\
\text { Body }\end{array}$ \\
\hline 1972 & 172090 & 1253.12 & 10906.08 & 8751.21 & 6480.61 & 2932.47 & 6853.8 & 4681.5 & 5191.07 \\
1984 & 301440 & 7684.27 & 9165.54 & 7144.32 & 5101.5 & 3695.03 & 3342.4 & 3634.24 & 7282.56 \\
2005 & 527802 & 12842.11 & 7888.13 & 3824.80 & 4164.42 & 5953.66 & 2239.66 & 2065.87 & 8071.21 \\
\hline
\end{tabular}

Source: Derived from 1991 and 2006 Census and Image Classification Analysis

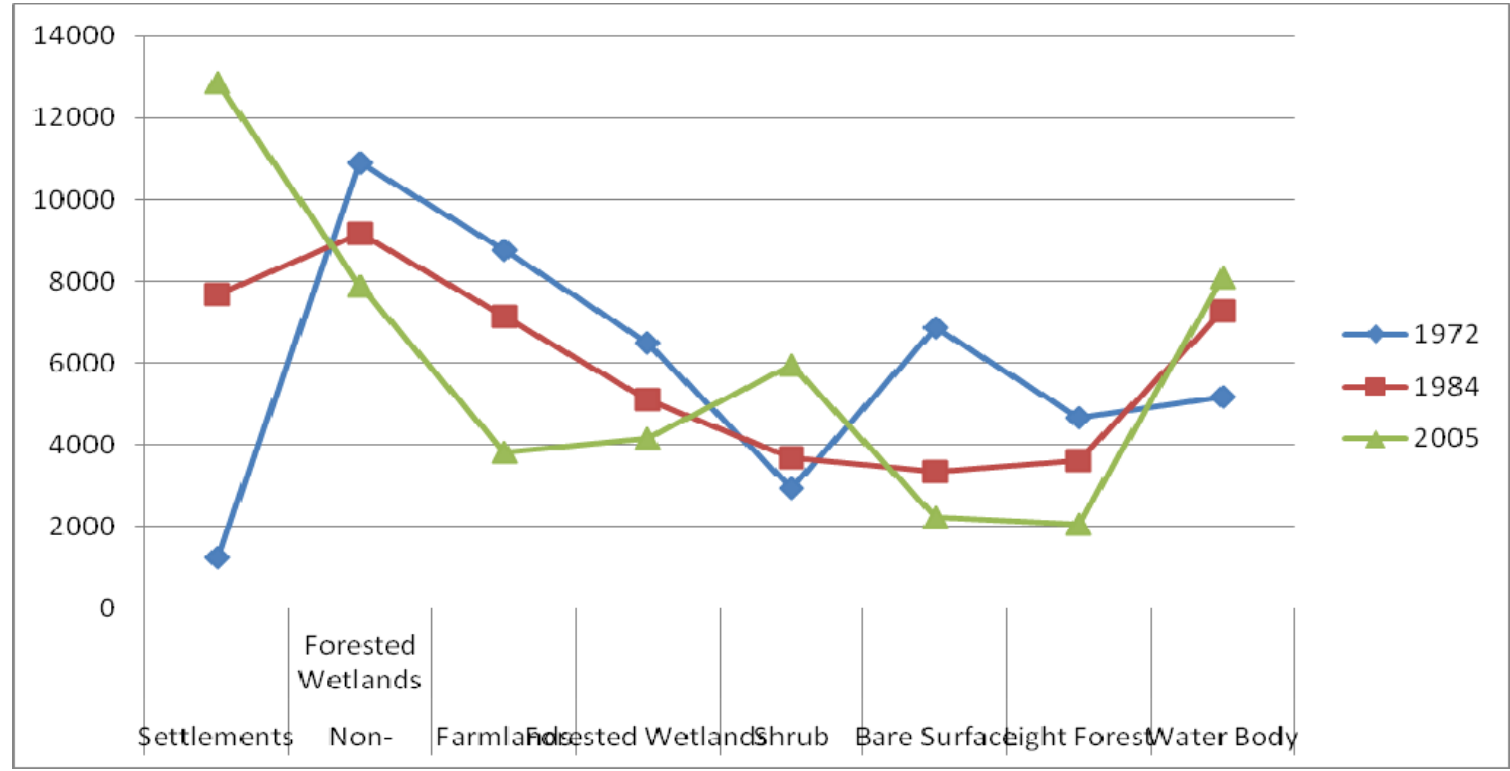

Figure 6: land use patterns of Abeokuta in 1972, 1984 and 2005

Population in conjunction with urbanization has always been important driven forces in land use dynamics. An attempt was therefore made to single it out as a major cause of changes in Table 8 . Here, it is observed that as the population was growing it caused instability among various uses to which lands were put. For instance, in the year 1972 when the population of Abeokuta was just 172,090 people, a paltry 1253.12 hectares of land was all that was required to meet the settlement needs of the people and 8751.21 hectares was for farming, an arrangement which typified an agrarian com- munity. In the year 1984, when the population increased from the 172,090 population figures of 1972 to 301,440 people, this increase triggered correspondent increase in the settlement lands from 1253.12 hectares of 1972 to 7684.27 hectares, farmlands, nonforested wetlands, forested wetlands. High forests were not spared in the encroachment of settlement lands, as they lose various hectares to settlements due to population increase.

In the same vein, the population kept increasing into the year 2005, with 527,802 
people. The settlement lands increased to 12,842.11 hectares, whereas it was 7,684.27 hectares in year 1984. Other land use types were also affected either with increase or decrease in their coverage. All the forest related coverage was reduced from their previous extent of 1984 in the year 2005. As a result of human occupation, even farmlands were reduced from 7,144.32 hectares of 1984 to $3,824.80$ hectares in 2005 . However, other land use types like shrubs and water body increased in their coverage in
2005 , to 5,933.6 and 8,071.21 hectares respectively; moreover, bare surface continued in its reduction in 2005 to $2,239.66$ hectares from the initial $6,853.8$ hectares of the year 1972. This reduction may not be unconnected with the city wide development, taking advantage of the already bare openings for the city expansion. Urban population growth has resulted in an increased pressure on land for housing and related services (Fanan et al, 2011).

Table 9: Projected Land use / Landcover values for the Study Area in 2020 from 2005

\begin{tabular}{lllllllll}
\hline & Settlements & $\begin{array}{l}\text { Non- } \\
\text { Forested } \\
\text { Wetlands }\end{array}$ & Farmlands & $\begin{array}{l}\text { Forested } \\
\text { Wetlands }\end{array}$ & Shrub & $\begin{array}{l}\text { Bare Sur- } \\
\text { face }\end{array}$ & $\begin{array}{l}\text { Light } \\
\text { Forest }\end{array}$ & $\begin{array}{l}\text { Water } \\
\text { Body }\end{array}$ \\
\hline 2005 & 12842.11 & 7888.13 & 3824.80 & 4164.42 & 5953.66 & 2239.66 & 2065.87 & 8071.21 \\
2020 & 20586.35 & 7137.96 & 2732.91 & 3650.08 & 9156.11 & 947.90 & 1512.99 & 8718.99 \\
\hline
\end{tabular}

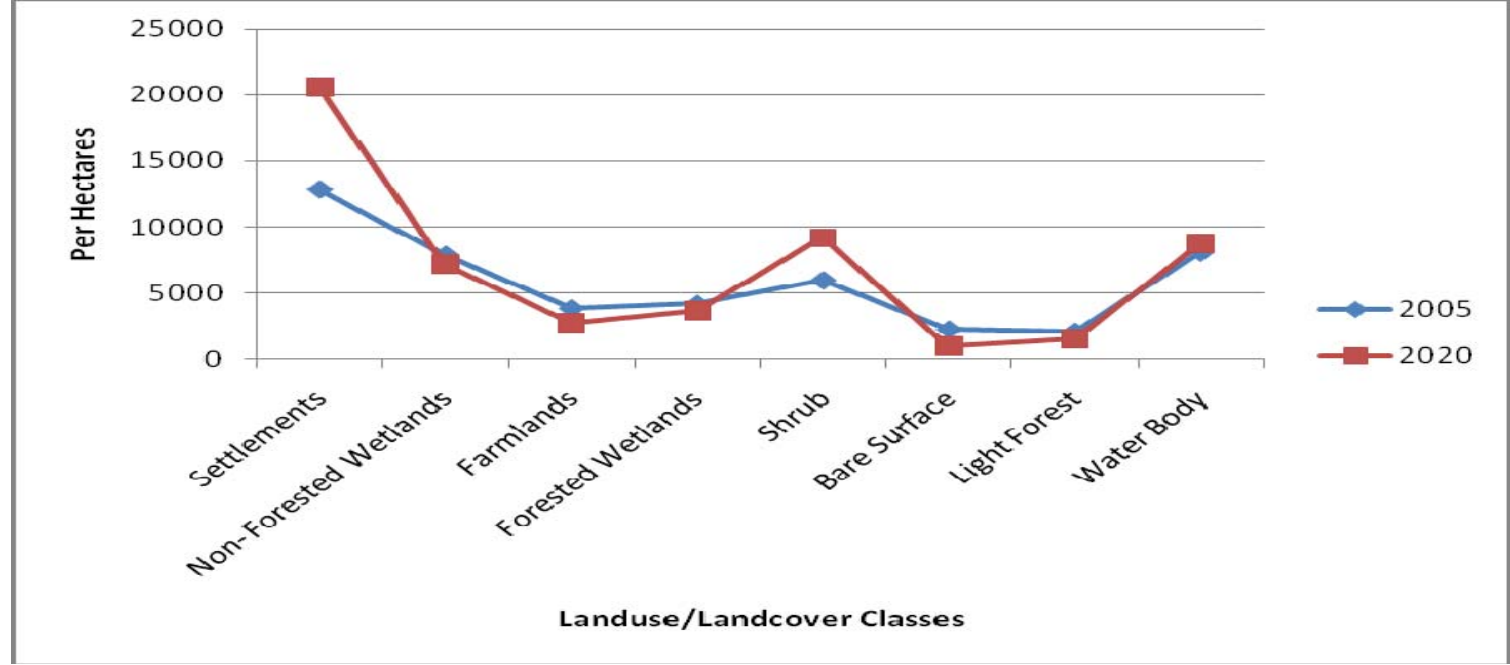

Figure 7: Projected Land use / Landcover values for the Study Area in 2020 from 2005

Table 9 and Figure 7 provided the likely land use projection for the year 2020 in the study area. This is instructive as it is a date set up during which significant improvement would have been achieved in the lives of at least of
100 million poor people (MDG, 2007). From the table, a total of 20586.35 hectares would be converted to settlement need of the people in the year 2020 as against the 12842.11 of 2005 . This repre- 
GIS - SUPPORTED ASSESSMENT OF LAND USE DYNAMICS OF ABEOKUTA ...

sented staggering $60.30 \%$ increase in settlement land needs in the year 2020, and again affirmed the notion of rapid urbanization of cities in the developing countries (Oyinloye, 2003, Menon 2004).

\section{CONCLUSION}

This study attempted a demonstration of the use of Geographic Information System and Remote Sensing in mapping and observation of change in the land use in Abeokuta metropolis part of south-western Nigeria. It incorporated field observation to show changes in land use. This study has revealed that geographic information system and remote sensing are adequate and suitable for assessing land use / landcover dynamics related problems confronting developing countries. The need to implement geographic information system and remote sensing centres, manned by well groomed experts in the profession, in all the local government councils of the fast growing cities in developing countries like Nigeria seems to be inevitable. Through which geospatial information generated from measurement will constitute the database that can be used for monitoring or predicting changes that may occur as a result of certain human activities. It was observed that there was general instability among the land use classes classified with attendant socioeconomic change in terms of change in, population status and growth, settlements expansion, occupational change and loss and illegal logging. However despite instability, settlement lands were the most dynamic land use classes throughout the period, hence rapid urbanization partly due to state creation. For these reasons there is need to discourage this trend to avoid the negative implication on the landscape, which in part may lead to loss of arable lands and heavy token on the forests related land cover. The findings of this research therefore bring to fore the need for a holistic assessment of anthropogenic activities, in Abeokuta and adaptations of sustainable management that will prevent unmonitored encroachment into other land use classes most especially by unregulated urban processes.

\section{RECOMENDATION}

The study therefore recommended that concerted effort should be made at regulating the expansion of the city, by ensuring strict compliance with layouts. The indiscriminate conversion of forest through illegal cutting of forest trees should be controlled. This will prevent loss of valued agricultural lands, and the avoidable consequence on the climate through ozone depletion. In addition, incentives such as fertilizer and other farm inputs should be provided for the farming populace in order to keep them on the same lands. If this is considered currently, it will prevent farmers from shifting to other virgin forests. Furthermore, agricultural lands should be considered as valuable and limited natural resources and as such, it should be managed and protected as other natural resources are managed. Since the study has shown that considerable agricultural lands are being lost to inevitable urban development annually, government should initiate policy and programmes, which may include revitalization of urban planning management in fast growing cities like Abeokuta. Urban dwellers in Abeokuta metropolis and other adjoining rural local governments, should be educated about the need to embrace vertical expansion instead of lateral expansion in urban land developments, such education will curb the encroachment of settlements / urban development on other land use types. Compulsory implementation of environmental impact assessments should be 
undertaken before any developmental structure is embarked upon; to determine desirability or otherwise of the intended projects.

In order to promote sustainable city development and prevent the uncontrolled settlements development, many of the respondents also suggested that all activities involving land use changes should be made to pass through the ministry of environment and rural development so as to ensure monitoring and implementation of various policies geared towards sustainable city developments. Urgent attention should be taken by governments at all levels to ensure that any urban development projects embarked upon is made to encroach only on bare surface otherwise referred to as waste lands. This will reduce the incidences of settlements lands increasing at the expense of other forest related land use classes arbitrarily.

\section{REFERENCES}

Adegboyega, S.A., and Aguda, A.S. 2010. The urban Sprawl Measurement in Egbeda Local Government Area, Ibadan; Ife Research Publication in Geography, Vol. 9 No, 1, 2010:Department of Geography, Obafemi Awolowo University, Ile- Ife. Pp 132-154

Ademiluyi, I.A. Okude, A.S. and Akanni, C.O. 2008. An appraisal of land use and landcover mapping in Nigeria, African Journal of Agricultural Research Vol. 3 (9), pp. 581-586, September 2008Available o n l i e a t ht t p : / www.academicjournals.org/AJAR ISSN 1991-637X (C) 2008 Academic Journals. Pp $1-6$

Adenekan, A. 2000. The Nation Gbagura; Ambassador for Christ publishers' inc., Abeokuta, Ogun State, Nigeria. p 6
Aketoyon, I.S., Ogundele, F.O. and Soladoye, O. 2010. Characterization by Factor Analysis of Chemical Faces of Groundwater in the Coastal Plain Sands Aquifer of Lagos, South Western Nigeria. Int'l J. of Academic Research. Vol. 2. No. 5, Sept., 2010.

\section{European Environment Commission} 2006. "An Analysis of Land Use/Land Cover Change Using the Combination of MSS Landsat and Land Use Map: A Case Study of Yogyakarta, Indonesia”. Int. J. Rem. Sens., 17(5): 931-944.

\section{Fanan, U, Kwabe I.D and Ifatimehin}

O.O 2011. Urban expansion and vegetal cover loss in and around Nigeria's Federal Capital City, Journal of Ecology and the Natural Environment Vol. 3(1), pp. 1-10, January 2011 Available online at http:/ / www.academicjournals.org/jene ISSN 20069847 C2011 Academic Journals. Pp 1-10

Fasona, M.J, and Omojola, A.S. 2005. Climate Change, Human security and Communal Clashes in Nigeria. Paper presented at an International Workshop on Human Security and Climate Change, Asker, Norway, 21-23 June, 2007.

\section{Food and Agriculture Organization} 2003a. Country Pasture/Forage Resource Profiles. Available On-line at http:// www.aginternetwork.netwhalecommwww.sci encedirect.com/wh alecom0/ Accessed July 26, 2016.

Fritts, J. 2005. Urban sprawl problems in Colorado. In Adegboyega, S.A., and Aguda, A.S. 2010. The urban Sprawl Measurement in Egbeda Local Government Area, Ibadan; Ife Research Publication in Geography, Vol. 9 No, 1, 2010:Department of Geography, 
GIS - SUPPORTED ASSESSMENT OF LAND USE DYNAMICS OF ABEOKUTA ...

Obafemi Awolowo University, Ile- Ife. Pp 132-154

Geist H, Lambin E, McConnell, W and Alves, D. 2005. Causes, Trajectories and Syndromes of Land - Use/Cover Change, UPDATE Newsletter of the International Human Dimensions Programme on Global Environmental Change, 03/2005, pp. 6-7.

Hardoy, J. Mitlin, D, and Satterthwaite, D. 2002. Environment problems in an urbanizing world: finding solution for cities in Africa, Asia and Latin America. Earth Scan Publications London. p 448

I.T.C 2005. Education 2005-2006. International Institute for Geo-Information Science and Earth Observation, Enschede .The Netherlands p 28.

Lohmann, L. 2006. Carbon Trading; A Critical Conversation On Climate Change. Privatization and power development dialogue N0 48 September 2006. Mediaprint Uddevalla Sweden, pp 1-362

Marshall, S. 2011. The Water Crisis in Kenya: Causes, Effects and Solutions. Global Majority E-Journal, Vol. 2, No. 1 (June 2011), pp. 31-45

Martine, G. 2011 Preparing for Sustainable Urban Growth in Developing Areas. An International Perspective United Nations Department of Economic and Social Affairs Population Division.: Part I Urban growth: Global trends and challenges. A Publication of the United Nation pp 1-30

Marzluff, J. M., Bowman, R. and Donnelly, R. 2001. A historical perspective on urban bird research: trends, terms, and approaches. In: Avian ecology and conservation in an urbanizing world. 1-17 pp. Ed. Kluwer Academic Press.

Millennium Development Goals Report (MDG), 2007. United Nation Statistical Divisions' Publication. New York, 2007, pp 121

Menon, N. 2004. Urban sprawl; A Developing Country Approach, A paper in the Ejournal of the WSC-SD Yale University, USA. Vol.2, No. 3, 2004, pp 125-141

\section{National Population Commission} (NPC), 2007. Federal Republic of Nigeria Official Gazette, Lagos

Nigeria Environmental Analysis Final Report (NEAFR), 2002 under USAID Contract No. LAG-I-00-99-00013-00 Biodiversity and Sustainable Forestry (BIOFOR) Indefinite Quantity Contract (IQC). P 10.

Nigeria Metrological Agency (NiMet) 2016. First Quarter Weather Bulletin for 2015. January - March 2014. www.nimet.ng.gov. accessed July 2016

Olaleye, J.B, Abiodun, O.E and Igbokwe, Q.C 2009. Land Use Change Detection and Analysis Using Remotely Sensed Data in Lekki Peninsula Area of Lagos, Nigeria. FIG Working Week 2009 Surveyors Key Role in Accelerated Development Eliat, Isreal, 3-8 May, 2009. Pp 1-15

Onakomaiya, S.O, Oyesiku, K., Jegede, J. 2000. Ogun State in maps. Geography, Regional Planning Dept. Olabisi Onabanjo University, Ago Iwoye: Rex Chales Publication Ibadan. PP 184-187

Oyinloye, R.O, 2003. Generation of Environmental Sensitivity Index (ESI) Map of 
Impact of Urbanization in Ibadan using re- Travel In Ogun State, Nigeria. Ethiopian mote sensing technique, unpublished M.Sc. Journal of Environmental Studies \& ManTheses, O.A.U, Ile-Ife. agement 7(2): $202-209$, ISSN: 1998-0507 doi: http://dx.doi.org/10.4314/

Oyegoke, S.O, and Sojobi, A.O 2012. Developing Appropriate Techniques to Alleviate the Ogun River Network Annual Flooding Problems, International Journal of Scientific \& Engineering Research, Volume 3, Issue 2, February -2012 1 ISSN 22295518 IJSER (C) 2012 http://www.ijser.org. pp 1-7

Reid, R.S, et al 2005. Global Changes in Land Cover, UPDATE Newsletter of the International Human Dimensions Programme on Global Environmental Change, 03/2005, p. 45.

ejesm.v7i2.12

UNEP 2002. Africa Environment Outlook: Past, Present and Future Perspectives, Earth print Limited, United Kingdom, http://www.unep.org/dewa/africa/ publications/aeo-1/010.html

Zubair, A.O, 2006. Change Detection in Land use and Land cover using Remote Sensing and GIS (A case study of Ilorin, Kwara State); an Unpublished M.Sc. Theses, Department of Geography, University of Ibadan, Nigeria.

Solanke, M.O 2014. Urban SocioEconomic Development And Intra-City

(Manuscript received: 28th October, 2015; accepted: 21st December, 2016 